Elsevier required licence: (c) <2019>. This manuscript version is made available under the CC-BY-NC-ND 4.0 license http://creativecommons.org/licenses/by-nc-nd/4.0/

The definitive publisher version is available online at https://doi.org/10.1016/j.jenvman.2019.04.114 


\title{
Analyzing the social impacts of scooters with geo-spatial methods
}

\author{
Alexey Voinov ${ }^{1,2}$, Javier Morales ${ }^{1}$, Hanneke Hogenkamp ${ }^{1}$ \\ 1 University of Twente, Enschede, The Netherlands \\ 2 PERSWADE Center, University of Technology Sydney, Australia
}

\begin{abstract}
Scooters, or gasoline powered two-wheelers, are becoming increasingly popular in the Netherlands. They provide fast, independent and affordable transportation, especially in urban congested areas. Unfortunately, they also have considerable adverse impacts on the environment and human health. The three most prominent impacts are associated with air pollution, noise pollution and traffic accidents. While the total contribution of emissions by scooters is relatively small compared to total traffic related emissions, they have a disproportionally large impact on their direct environment, especially when sharing roads with bicycles as in the Netherlands, where they are characterized as super-polluters. A scoping GIS based assessment, using theoretical and available secondary data, could identify routes with highest likelihood of scooter presence to estimate exhaust and noise impacts and related traffic accidents. Estimated are provided for the total population, and the number of childcare facilities within the impact areas. For future projections four different scenarios are analyzed. For the case study of the town of Enschede in the Netherlands the present noise/exhaust environmental impact of scooters is affecting at least $30 \%$ of the population and in the future this number can increase to $38 \%-53 \%$.
\end{abstract}

\section{Keywords}

GIS, air pollution, traffic accidents, noise, buffer analyses

\section{Highlights}

Gasoline powered two wheelers aka mopeds or scooters are gaining popularity

Scooters are super polluters creating air and noise pollution and causing accidents

Management and regulation are needed to encourage use of electric scooters

\section{Introduction}

In the last 10 years the number of scooters in the Netherlands has been steadily increasing. Within Europe, the Netherlands is the country with the highest use of scooters: almost 60 scooters per 1000 inhabitants (Ewalds, Mortiz, \& Sijstermans, 2013). This is remarkable since one would expect scooters to be more popular in Southern Europe where weather conditions are more favorable for their use (Dall'Osto \& Querol, 2013).

There may be several reasons for this. First, they offer a fast solution in urban congested areas with easy parking options. They also take advantage of existing traffic regulations, which allow scooters on bike lanes. Second, they are more affordable than cars both to purchase and maintain. Thirdly, independent mobility is becoming an increasingly important part of quality of life (Dall'Osto \& Querol, 2013). Often scooter riders are described as 'risk takers', 'sensation-seekers' and 'speed-rebels' (Njå \& Nesvåg, 2007), which also attracts some users, especially among youngsters.

There are two types of scooters in the Netherlands, distinguished in terms of their legal maximum speed: $25 \mathrm{~km} / \mathrm{h}$ for the so-called light-mopeds and $45 \mathrm{~km} / \mathrm{h}$ for the regular mopeds. Wearing a helmet is mandatory for moped riders but not on light-mopeds (Methorst, Schepers, \& Vermeulen, 2011). Also, their position within the road network is different: lightmopeds are restricted to designated bike and moped/bike lanes while mopeds are allowed on 
bike paths only in special cases (Rijksoverheid, 2013). In many cases the same type or brand of vehicles can be used for both types of scooters, only for light-mopeds a speed limiter is added. These speed limiters make scooters more energy-inefficient and more polluting (Hensema et al., 2013). As Figure 1 shows since 2013 there are more light-mopeds in the streets than regular mopeds. Light-mopeds are preferred by older people, while mopeds are more popular among youngsters (CBS, 2013).

According to Dall'Osto \& Querol (2013) "there is an extraordinary contrast between the lack of knowledge on powered two wheelers (PTW) in the literature and their rising trends in many urban areas". The three most prominent impacts of scooters are air pollution, noise pollution

Figure 1. Numbers of scooters in the Netherlands, 2007-2013. Source: CBS (2013)

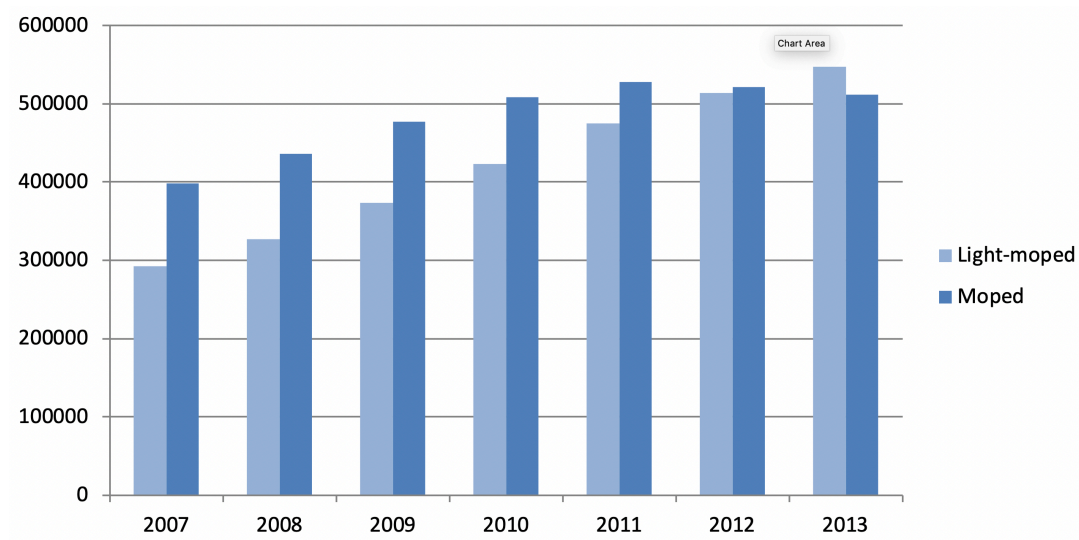

and traffic accidents.

Next to traffic participants, scooters also impact people living along roads.

When the proportion of PTWs in the circulating fleet is high enough, urban air pollution can be strongly influenced by their emissions, and it is no longer negligible in comparison to what modern passenger cars contribute (Prati

\& Costagliola, 2009). Boogaard et al. (2009) investigated the exposure to ultra-fine and fine particles during cycling and observed that when mopeds were passing by, the number of particles increased by $58.4 \%$ while for cars - only by $3.7 \%$. Many of the PTWs are powered by two-stroke engines, which have hydrocarbon $(\mathrm{HC})$ emission rate approximately six times that of the typical four-stroke engine (EPA, 1991). In another study, benzene and other HC exposure levels with two-stroke engines were vastly exceeding those from four-stroke and diesel engines: 58.4, 38.9 and $15.7 \mu \mathrm{g} / \mathrm{m}^{3}$, respectively (Kirrane et al., 2007). According to BOVAG (a trade association of some 9,500 entrepreneurs engaged in mobility) approximately 25\%-33\% of the scooter fleet in 2014 in the Netherlands were two-stroke (Weijer van de, 2014).

Hensema et al. (2013) compared the emissions of different Euro-2 scooters (2-stroke versus 4-stroke, light-moped versus moped) and also compared them to passenger car emissions. Both the Euro- 5 diesel and petrol car performed orders of magnitude better on $\mathrm{HC}$ and carbon monoxide (CO) emissions than the Euro-2 scooters. In terms of particulate matter (PM) and nitrogen oxides $\left(\mathrm{NO}_{\mathrm{x}}\right)$, a 2-stroke scooter emits significantly more than a 4-stroke scooter and petrol cars, while diesel cars have much higher $\mathrm{NO}_{\mathrm{x}}$ emissions than all other vehicles.

In addition to benzene moped exhaust contains 1,3-butadiene; both are confirmed human carcinogens. $\mathrm{CO}$ interferes with oxygen transport to the cells of the body. Formaldehyde, acrolein and NOx in exhaust are all irritants and may exert other systemic effects (Heil and Pargal, 1998; Dost, 2010). What makes it even worse in the Netherlands is that scooters share the lanes with bikes, so that the exhaust gasses are more or less directly spewed into the lungs of cyclists, who have no way to avoid them, and due to their physical activity have a higher respiration rate than at rest.

When the exposure of residents to air pollutants is long and intense, the impact on their health becomes greater. The long-term effects range from minor eye irritations and respiratory symptoms to decreased lung/heart functions and even premature death (Biju \& Vijayan, 2014). On the other hand, short-term increase in fine PM pollution concentration already leads to increased blood pressure within a period of a few days, while long-term exposure also causes chronic hypertension (Brook \& Rajagopalan, 2009). Next to elderly people, children are also more sensitive to traffic pollution health impacts compared to adults. 
A number of studies found a correlation between the incidence of asthma in children and long-term exposure to nitrogen dioxide (Favarato et al., 2014).

The noise produced by scooters is seen as the most annoying traffic noise source. Especially cyclists and pedestrians are affected (Vos, 2006). Since scooters are mostly used in urban areas, the physical characteristics of urban terrain, like the location and shapes of buildings, also have a significant influence on noise propagation and the acoustic environment (Paviotti \& Vogiatzis, 2012). Also, the tendency to tamper with moped's components is often a cause for additional noise pollution (VROM, 2010). According to a study by den Boer and Schroten (2007) the problem is that owners modify their mopeds by, for example, replacing the original exhaust silencers by less efficient and noisier ones. Overall, this has been registered in $65 \%$ of all mopeds in Europe.

For road traffic, people experience nuisance from noise over $38 \mathrm{~dB}$. Long-lasting exposure to $80 \mathrm{~dB}$ and higher can cause deafness (Rijkswaterstaat, 2010). The reported levels of decibels for a scooter varies from $73 \mathrm{~dB}$ (Mohapatra, 2004) to $80 \mathrm{~dB}$ (Rana, 2008), and to $81 \mathrm{~dB}$ (Paviotti \& Vogiatzis, 2012). In all research, the mean level of noise produced by scooters lies 4-5 decibel above the noise produced by cars. As with the emissions data, there is more data for car noise levels, but limited data for scooters (Paviotti \& Vogiatzis, 2012). No data was found about the distinction of noise emissions between light-mopeds and mopeds, 2-stroke and 4-stroke models, etc.

In literature the noise impact of traffic is also related to various diseases. Research by Passchier-Vermeer \& Passchier (2000) indicates that traffic noise disturbance can lead to health impacts such as hearing impairment, hypertension, heart diseases and sleep disturbances. As with exhaust pollution, also here the children are regarded as a risk group that is more sensitive to traffic noise. Besides decreased school performance, also higher blood pressure is observed among children in noisy environments compared to those in quieter places.

The safety aspect is also important to keep in mind. PTW riders have a relatively high risk of being involved in accidents. This has mainly to do with the riding speed in combination with the rider's vulnerability. Also, the largest portion of the scooter riders are young people (16-18 years, mainly moped riders) and elderly people (60 and older, mainly light-moped riders), both of which are seen as risk groups (SWOV, 2009). Research has shown that the fatality rates for PTW riders are 20-40 times higher per distance travelled than for car drivers (Blackman \& Haworth, 2013). Despite the fact that PTWs have legal maximum speeds, research in the Netherlands shows that the mean speed of light-mopeds is $34 \mathrm{~km} / \mathrm{h}$ and for mopeds $54 \mathrm{~km} / \mathrm{h}$, which is already over the speed limit and means that there are numerous violations of the regulation here. Since scooters often have to share the road with cyclists, with the big difference in their speed, the threat is not only for scooter riders but even more to the cyclists (Methorst et al., 2011). Still, according to Steg \& Brussel (2009), there is little research conducted on the factors influencing scooter related accidents, and on ways to reduce the high risks.

It can be concluded that although the global impact of scooters may not be significant, their local impact can be very high. If not controlled, the use of PTWs is likely to continue to increase for at least the next decade. The challenge is to adopt suitable strategies to mitigate the safety and health issues associated with this (Haworth, 2012) or develop regulations that would restrict the expansion of the scooter fleet and/or control their impact. Neglecting the role of scooters can result in health and life hazards. Regulating PTWs is certainly one of those wicked problems so prevalent in environmental management. On the one hand the hazardous impacts of PTWs are profound and known, on the other hand there is a growing number of people who find themselves attached and dependent on this mode of transportation. Despite the externalities they create they prefer to continue to use their PTW and are likely to oppose any restrictions that may be legislated.

The goal of this research is to assess the current and future spatial environmental and social impacts of scooters. The expectation is that by providing improved visualizations and quantification of the PTW impacts on humans, we can assist urban managers and decision makers to improve existing regulations while making these changes more likely to be accepted by the general public. The municipality of Enschede is chosen as the study area. The choice was largely driven by the availability of data. On the other hand, Enschede is a 
typical average sized municipality in the Netherlands, so the results of the analysis can be easily extrapolated to other such places in the country and beyond.

\section{Methodology and data used}

The effect of traffic on health and safety is disproportionately distributed over space. Living near busy roads is associated with health hazards. Biking or walking along roads with high scooter traffic exposes residents to higher noise and toxic pollution, as well as increases the risks of being involved in scooter related traffic accidents. To assess the health and environmental impact of scooters we need to identify the intensity of scooter traffic along the road network and then compare that with the distribution of residential population, especially those elements of it that are most vulnerable.

\section{Methodology}

Jerrett et al. (2005) categorize air dispersion modeling methods into six classes.

- Proximity based methods measure the proximity of a subject to a pollution source.

- Geostatistical methods that measure pollutants at a set of monitoring stations distributed over the study area.

- Land use regression models predict pollution concentrations at a given site based on surrounding land use and traffic characteristics.

- Dispersion models generally use Gaussian plume equations. Meteorological conditions and topography are used in estimating the spatial extent of air pollutants.

- Integrated meteorological-emission models that combine meteorological and chemical modules to get more insight in the pollutants dynamics.

- Hybrid models, combining personal/regional monitoring with air pollution dispersion methods.

The data requirements for each of the six methods are increasing with the complexity of models assumed.

Probably because of its low cost and availability of updated data, an increasing number of studies rely on the proximity-based method using data on the road network and vehicle traffic as an indirect measure of atmospheric pollution in urban areas. In our case, when developing a scoping tool that could be used in a variety of locations, with no specific monitoring data available, this was the obvious choice. Studies have shown that the concentration of pollutants close to roads are well correlated to traffic counts, so that the latter can be used as an indicator of exposure of urban residents to atmospheric pollutants (Habermann, Medeiros, \& Gouveia, 2011). When exposure to traffic exhaust shows different magnitudes within small differences in proximity, buffers can be mapped along the roads distinguishing the areas and population with elevated exposure to traffic exhaust (Albert, Gesler, \& Levergood, 2000). In the majority of research, the residential mobility is not considered. People do often move or spend most of their day at other places than their homes; so, ignoring this can certainly cause errors (Habermann et al., 2011).

Density of traffic on road segments can be used to discover 'hot routes' ( $\mathrm{Li}$, Han, Lee, \& Gonzalez, 2007). In San Francisco the traffic intensity on each road segment was used to calculate an estimated kernel density, which is a land use modeling method that produces a smooth surface over the city area (SCl, 2014). Traditionally, a kernel density estimation (KDE) function has been widely used to analyze point patterns like traffic accidents, but with new upgrades in, for example, ArcGIS, KDE now also can be used to study characteristics of networks (Cai, Wu, \& Cheng, 2013). In our study we have chosen to rely mostly on Geographic Information System (GIS) techniques and some of the standard data sets 
available for most of the Netherlands. This makes it more likely that the approach can be used for other locations beyond the case study we chose.

To streamline our analyses, a script was developed to run all the procedures iteratively and repeatedly (Fig.2). The script was divided into six subroutines:

- Phase A: selection of scooter owners for work, shopping or education purposes

- Phase B: division of destinations among city parts for work and shopping purposes

- Phase C: route analysis for work

- Phase D: route analysis for shopping

- Phase E: route analysis for education

- Phase F: merging all routes.

In phase A, the number of scooter owners is distributed over the neighborhoods in proportion to residential buildings there. Statistical analysis results in proportions of scooter owners for commuter traveling, shopping and education. These three proportions are used to randomly select owners.

Figure 2. The script used for analyses.

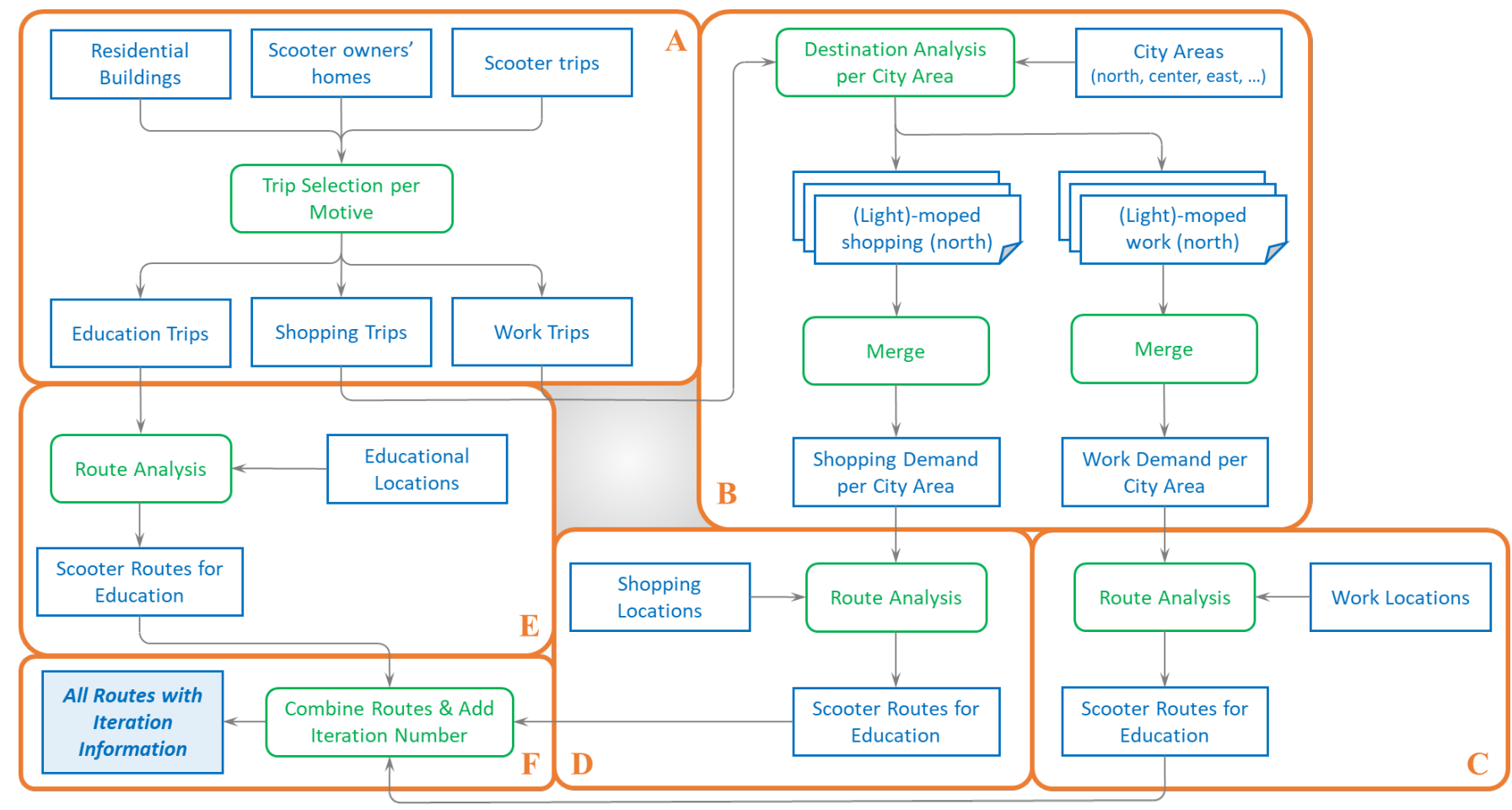

In phase $B$, the proportion of population within each city part is calculated and then used to divide the population over the five work and education city destinations.

Phases $C, D$ and $E$ focus on the calculation of the routes for each of the three trip motives. In phase $F$, the routes produced by the three different trip motives are merged together to obtain combined route information (green result in Fig.2). Since there is some stochasticity involved in this analysis, the script is run several times and the average of the results is taken.

The following approach has been used to analyze scooter traffic and their impact on the urban environment.

Scooter flows are calculated on a daily basis to determine the number of scooter trips per road segment. Then a kernel density analysis method is used with a search distance of 30 meters to calculate the density of features (e.g., houses, businesses) in the various neighborhoods of the city. The population of each neighborhood is defined by the number of scooter owners living in each neighborhood. 
The kernel density analysis output is a floating-point raster with high values for areas where high scooter counts are present. The values are then classified into five different categories, which describe the chance to encounter a scooter: very low, low, moderate, high and very high. Since concentrations of pollutants are closely correlated with traffic counts, a combination of the kernel density analysis and buffer analysis (proximity modeling) is used to analyze the exhaust impact. Once the impact areas are identified within the municipality, buffer analysis is used to calculate the impact on the population and childcare facilities, in particular.

For the exhaust impact, the timing of scooter travel also matters. Ten scooters passing one after another will certainly create a much higher impact than the same number of scooters traveling once an hour. For this reason, only the work and education travel motives were considered as they happen in very narrow and well-defined time windows. These two motives, produce activity concentrated over the so-called rush-hour periods in the morning and in the evening. For shopping purposes scooter riders are more likely to be evenly spaced over the whole day, making their impact relatively less pronounced.

The buffer sizes representing the exhaust impact zones for each pollutant are determined using distance decay parameters taken from literature.

The noise impact is calculated in the same way. Here again only the routes with work or education purposes are used. An additional factor is considered when creating the buffers for noise assessment, that is, the number of buildings within the first 100 meters from roads. When there are buildings on road segments they will dampen the noise propagation and decrease the noise disturbance caused by scooters. For example, if $10 \%$ of the $100 \mathrm{~m}$ zone on one side of the road has buildings, the buffer size on that side is reduced to $0.9^{\star} 240=216$ $\mathrm{m}$.

Scooter related accidents are analyzed using three different methods. First, the exact locations of accidents (distance from junctions) within the network are identified. Second, statistics about the number of scooters on the road segments where scooter accidents have occurred in the past are obtained. Third, again kernel density analysis is used to determine whether there is a spatial relationship between accidents and scooter routes.

\section{Data used}

The complete list of data sources is given in the Appendix. We have chosen to rely entirely on open data that is available on the Internet or could be accessed through inquiries with the Enschede municipality.

From the OViN 2012 records (CBS, 2014b) it was clear that scooter owners use their scooters mainly for commuter traveling, daily shopping and education. Other motives like visits and recreation are hard to associate with particular destinations (e.g. no information from individuals about family members or friends and their locations). These motives are also more sporadic. Commuter traffic, shopping and education activities are performed (almost) every day, definitely on a weekday.

The database on research mobility flows for Twente was used to further explore the actual flows of people, especially for shopping and commuter traveling purposes. Education locations are secondary schools, intermediate vocational education (MBO) facilities, higher vocational (HBO) schools and the University of Twente.

To identify the work locations, a fairly course resolution (large polygons) business area dataset was combined with BAG data for buildings with work occupancy in those polygons. For the shop locations, the Retail Business Structure Vision 2011 document (Gemeente Enschede, 2011) was used. Daily shopping includes visits to the supermarket, special retailer (tobacco, liquor store etc.) and personal care shops (Gemeente Enschede, 2011).

The locations of scooter owners where approximated using the information about postal codes and the BAG data about neighborhoods. The neighborhood data is more detailed (70 neighborhoods vs. 23 postal codes). However, the CBS information on light-moped and moped owners is postal code based. To approximate the postal code data to the actual neighborhoods and addresses we have used the BAG data on particular buildings and their occupancy and have distributed the moped owners in postal codes in proportion to the total number of address locations in these postal code areas. 
The Open Street Map (OSM) vector data were used to create two road networks: one for light-mopeds, which can use bike paths, and one for mopeds. The A35 highway was excluded from the network since it is not accessible to all scooters. Additionally, unpaved roads, often located in the rural areas of the municipality, were removed. Map images from the Dutch Cyclist' Union were used to identify the bike paths, which are also accessible for light mopeds.

For each moped type two speed attributes were assigned to roads to distinguish between the movement within the built-up areas and beyond (Table 1). We assumed that in rural areas,

Table 1. Maximum allowed speed in $\mathrm{km} / \mathrm{h}$

for light-mopeds and mopeds within and outside of residential areas with no traffic lights and speed bumps, the average speed will be higher than in built-up areas. We also distinguished between 'primary' and

Location Light-moped Moped 'secondary', connecting, roads as identified by

Within $\quad 20 \quad 30$

Outside $\quad 30 \quad 45$ OSM. The average speed on primary roads is higher than on secondary roads in neighborhood areas where we find playing children, speed bumps, parked cars etc. Although small shortcuts through neighborhoods can save time, in reality people usually stay on the main roads because they are faster.

The BAG data (Kadaster, 2014) were also used to identify the locations of primary schools and childcare facilities. Information on scooter accidents from 2009-2012 has been obtained from the department of National Public Works and Water. The accidents of 2013 were obtained via the website http://ongelukken.staanhier.nl/.

\section{Results}

For both the present day and future scenarios we have analyzed four factors: major scooter routes, exhaust impact, noise impact and scooter related accidents.

\section{Present}

To analyze the current situation, 2014 was picked as the base year, when 10,811 scooter owners were living in the municipality of Enschede. Approximately $65 \%$ of scooter trips were used for work purposes, $20 \%$ to go

Figure 3. "Cold/hot spots" for scooter encounters on a daily basis in Enschede

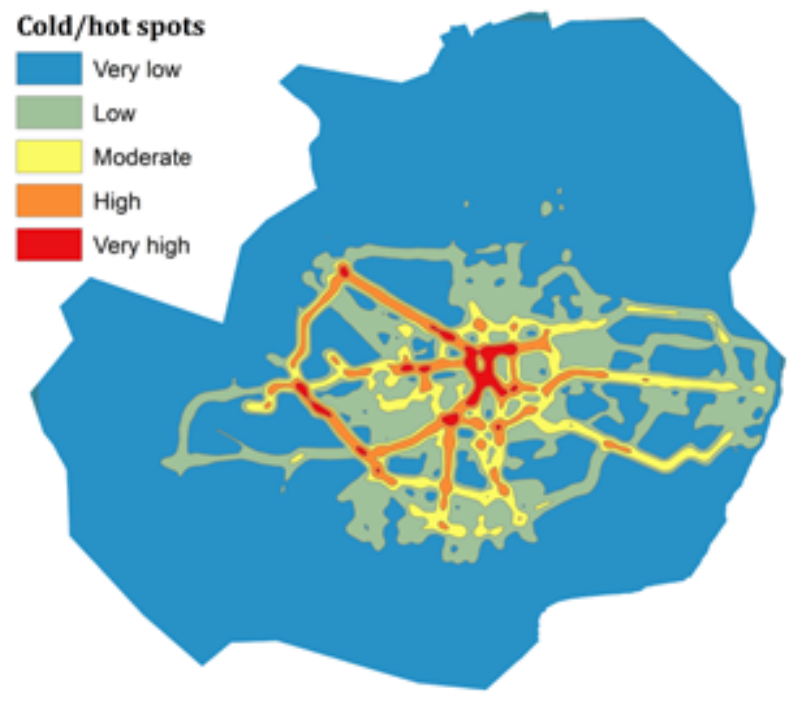
shopping and $15 \%$ to go to school.

Figure 3 presents the kernel density analysis for the daily number of scooters in the municipality of Enschede. In a cold spot the chance to encounter a scooter is low, while in a hot spot the chance is high. As one would expect the highest scooter traffic is in the center. The relatively high traffic density in the West can be explained by numerous employment opportunities in that part of the city, including the University of Twente campus in the North-West.

Based on this traffic map the exhaust pollution can be analyzed by also applying the kernel density analysis method while focusing only on the routes to work and educational destinations. For each 
road segment, the maximum values of the morning and afternoon pollution levels are calculated. Next buffer analysis is performed for $\mathrm{CO}, \mathrm{NO}_{x}$ and $\mathrm{HC}$ using buffer sizes of 170 , 115 and $180 \mathrm{~m}$, respectively, which are the decay parameters for these gases.

The resulting buffer zones are intersected with the population dataset, which gives the average number of residents per building. Table 2 shows the proportion of population per impact area for the three types of exhaust gases. The $\mathrm{HC}$ has the largest distance decay range, and reaches the largest proportion of population: $36 \%$ in the "high - very high" impact classes. Correspondingly, $27 \%$ of population are exposed to "high - very high" impact from $\mathrm{NO}_{x}$, and $34 \%$ suffer from "high - very high" concentrations of $\mathrm{CO}$.

Figure 4 presents a map fragment demonstrating how a part of the inner city of Enschede

Figure 4. Example of HC impact classes on the population in the was subdivided into inner-city of Enschede

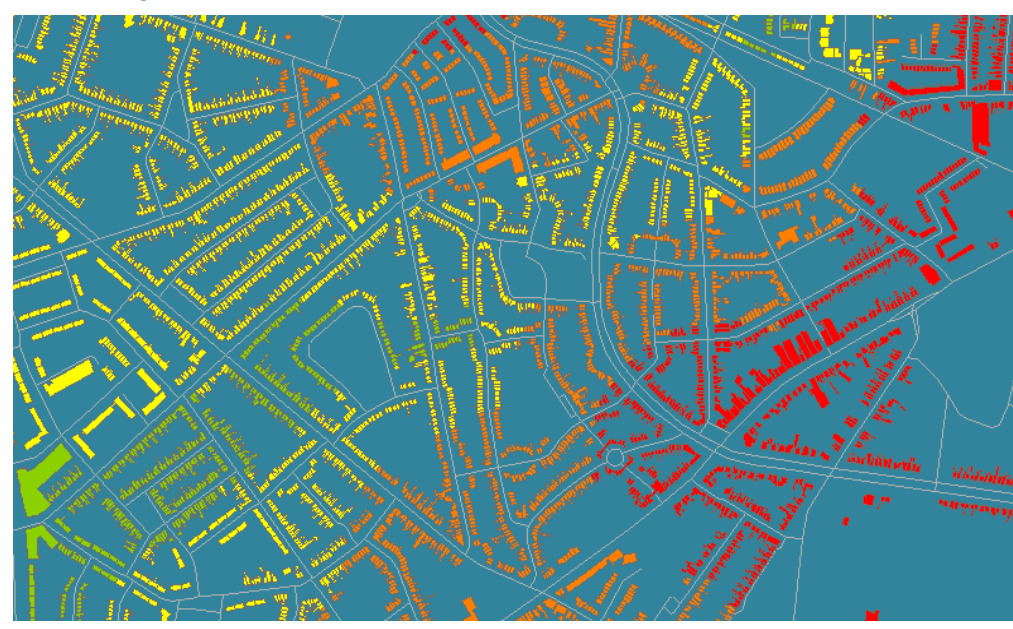
various impact classes. The population allocated to the highest impact classes are basically all those living in the central part of the city, while the two lowest impact classes are mainly in the outskirts. In the central part of the municipality most of the buildings are large apartment houses, with high concentration of population, putting many residents into the very high impact zones, though most likely people living on higher levels would be exposed to lower concentrations of exhaust gases than what is shown here.

Separately the exhaust impact on children was assessed by intersecting the exhaust buffers with childcare facilities. From the 99 facilities, 38\% (for CO), $23 \%$ (for $\mathrm{NO}_{x}$ ) and $40 \%$ (for $\mathrm{HC}$ ) are located in areas where the impact of scooters is "high - very high" (Table 2). Facilities with the "very high" class of exposure are mostly located in the city center, while the "high" impact class facilities are located in the eastern part of the municipality.

Table 2. Proportion of population and childcare facilities per impact area for $\mathrm{CO}, \mathrm{NO}_{\mathrm{x}}$ and $\mathrm{HC}$

\begin{tabular}{lllllll} 
Impact class & $\mathrm{CO}$ & \multicolumn{2}{c}{$\mathrm{NO}_{\mathrm{x}}$} & $\mathrm{HC}$ \\
& \% population & \% childcare & $\%$ population & \% childcare & \% population & \% childcare \\
Very low & 11 & 6 & 15 & 10 & 11 & 6 \\
Low & 32 & 35 & 35 & 37 & 31 & 34 \\
Moderate & 23 & 21 & 22 & 30 & 22 & 20 \\
High & 23 & 23 & 20 & 16 & 25 & 23 \\
Very high & 11 & 15 & 8 & 7 & 11 & 17
\end{tabular}

The noise pollution is also analyzed for five impact classes. The distance parameter in this case is $240 \mathrm{~m}$, with proportional reductions when there are buildings along the roads.

Following the same conservative reasoning as with the exhaust pollution analysis, only the routes used for work or education purposes are included. Table 3 shows how the population will be impacted by noise. $36 \%$ of the population lives in areas with a "high - very high" probability of noise disturbance from scooters. 
Table 3. Proportion of population and childcare facilities for the noise impact area

\begin{tabular}{lcc} 
Impact class & \multicolumn{2}{c}{ Noise } \\
& \% population & $\%$ childcare \\
Very low & 10 & 6 \\
Low & 31 & 35 \\
Moderate & 23 & 18 \\
High & 25 & 26 \\
Very high & 11 & 15
\end{tabular}

The noise impact distance decay parameter is the highest among the four parameters used in this analysis. However, accounting for noise reduction by buildings, results in more or less the same number of affected people per class, as with $\mathrm{CO}$ and $\mathrm{HC}$. Here the same conclusion could be made as with the exhaust pollution: the population with a high chance to suffer from noise disturbance is mostly located in the center of the municipality. The impact of PTW noise also affects children development by causing learning difficulties. Around $41 \%$ of the childcare facilities are located in areas where the scooter noise disturbance impact is "high - very high" (Table 3).

When analyzing accidents involving scoters, a

distinction between light-moped and moped scooters is made. As seen in Table 4, about half of accidents involving both light-mopeds and mopeds, occur within 10 meters from junctions. When this distance increases, the number of accidents gradually decreases. Interestingly $\approx 88 \%$ of the accidents occur within 50 meters from an intersection.

Table 4. Number of light-moped and moped accidents per distance class from junctions

\begin{tabular}{cllll} 
Distance $(m)$ & \multicolumn{2}{l}{ Light-moped } & \multicolumn{2}{l}{ Moped } \\
\hline & Abs & $\%$ & Abs & $\%$ \\
$<10$ & 47 & 53 & 113 & 57 \\
$10<20$ & 10 & 12 & 20 & 10 \\
$20<30$ & 9 & 10 & 18 & 9 \\
$30<40$ & 8 & 9 & 12 & 6 \\
$40<50$ & 3 & 3 & 11 & 5 \\
$50>$ & 11 & 13 & 26 & 13
\end{tabular}

They are especially high in the "high - very high" classes.
The mean number of scooters traversing a road segment on a daily basis is 21 . The mean number of scooters involved in accidents on a daily basis is: 61 for lightmopeds, and 56 for mopeds. This indicates that scooter accidents in general occur at places where more scooters are passing by than on average. Table 5 shows the numbers for OSM links, light-moped and moped accidents, per cold/hot spot class (as in Figure 3). In comparison to the relative proportion of OSM links within every class, the scooter accidents are underrepresented in the "very low - low" classes. In the other three classes, the scooter accidents are overrepresented in comparison to the proportion of OSM links within those classes.

Table 5. Number of OSM links, light-moped accidents and moped accidents per scooter number class, both absolute and relative

\begin{tabular}{|c|c|c|c|c|c|c|}
\hline & \multicolumn{2}{|c|}{ OSM links } & \multicolumn{2}{|c|}{ Light-mopeds } & \multicolumn{2}{|c|}{ Mopeds } \\
\hline & Abs & $\%$ & Abs & $\%$ & Abs & $\%$ \\
\hline Very low & 2904 & 22 & 3 & 4 & 17 & 8 \\
\hline Low & 5332 & 41 & 24 & 27 & 73 & 37 \\
\hline Moderate & 2194 & 17 & 22 & 25 & 43 & 21 \\
\hline High & 1832 & 14 & 30 & 34 & 44 & 22 \\
\hline Very high & 754 & 6 & 9 & 10 & 23 & 12 \\
\hline
\end{tabular}


The number of scooter accidents within the identified cold/hot spot areas on major route sections was used to estimate the number of accidents per area classification. In Figure 5, a clear pattern emerges showing more accidents in the "high-very high" impact areas.

Figure 5. Location of scooter accidents within the cold - hot spot areas based on daily scooter counts

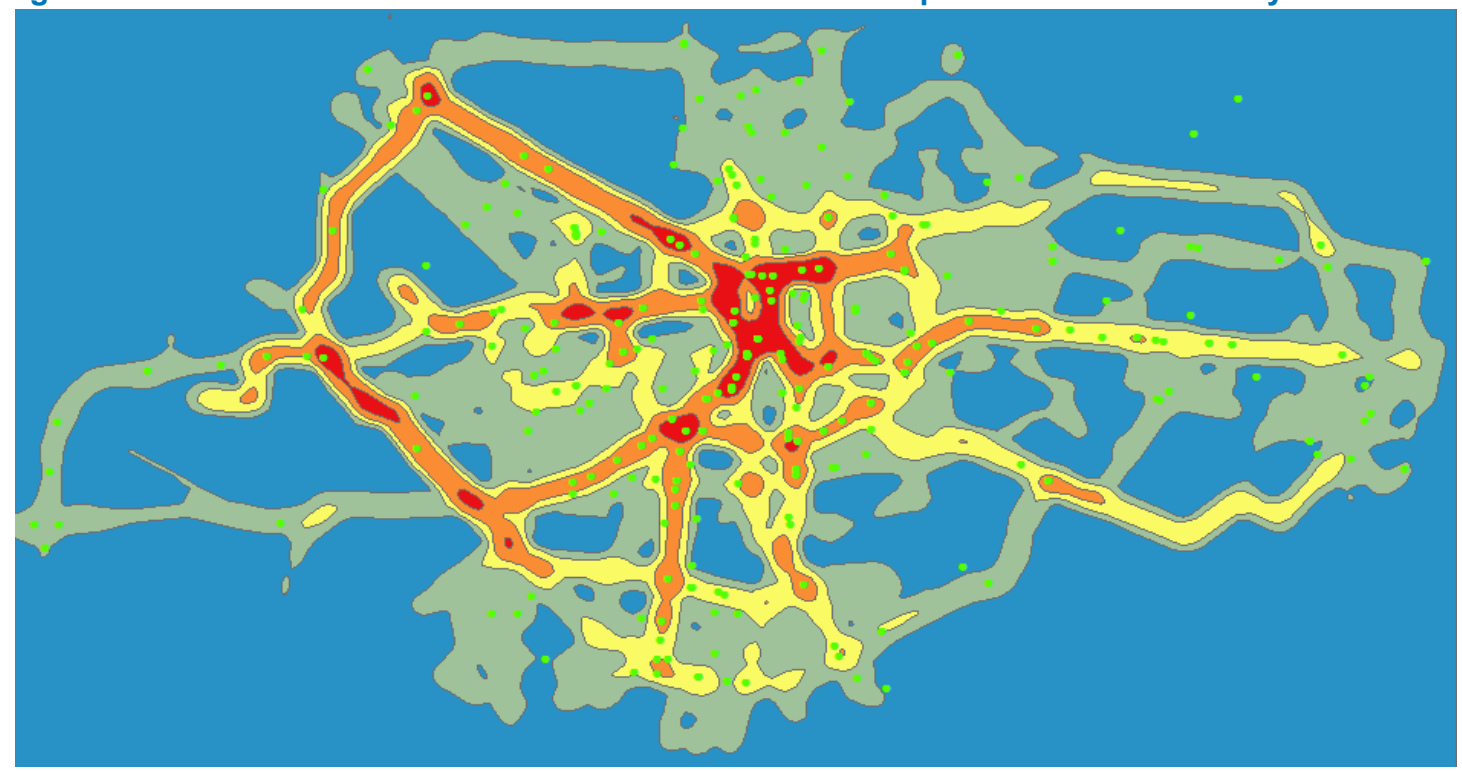

\section{Analyses of future scenarios}

Four different scenarios were considered, using two extrapolation techniques (linear and logarithmic regression) to estimate the future "number of owners" and "proportion of scooter use for work, shopping and education purposes". All other parameters remained the same as in the present situation.

* Scenario A: linear regression for scooter owners.

* Scenario B: logarithmic regression for scooter owners.

- Scenario C: linear regression for scooter owners and increase of work, education and shopping purposes proportion by $30 \%$.

* Scenario D: logarithmic regression for scooter owners and increase of work, education and shopping purposes proportion by $30 \%$.

The resulting numbers of scooter riders in the municipality in the different scenarios are shown in Table 6.

We present the results for all the four scenarios simultaneously, which will also serve as a kind of sensitivity analysis.

Table 6. Scenarios overview; number of (light-moped) owners for work, shopping and education purposes

\begin{tabular}{l|llllllll} 
Scenario & \multicolumn{2}{c}{ Work } & \multicolumn{3}{c}{ Education } & \multicolumn{2}{c}{ Shopping } & Total \\
\hline & Light-moped & Moped & Light-moped & Moped & Light-moped & Moped \\
Scenario A & 1,248 & 434 & 336 & 117 & 296 & 103 & 2.534 \\
Scenario B & 936 & 470 & 252 & 127 & 222 & 112 & 2,119 \\
Scenario C & 1,623 & 563 & 437 & 152 & 385 & 134 & 3,294 \\
Scenario D & 1,217 & 611 & 328 & 164 & 289 & 145 & 2,754
\end{tabular}

This is also reflected in the patterns of cold-hot spots corresponding to these scenarios (Figure 6). In general, the pattern does not change significantly, but in scenario $C$, which has 
Figure 6. Cold/hot spots based on scooter day counts for each scenario
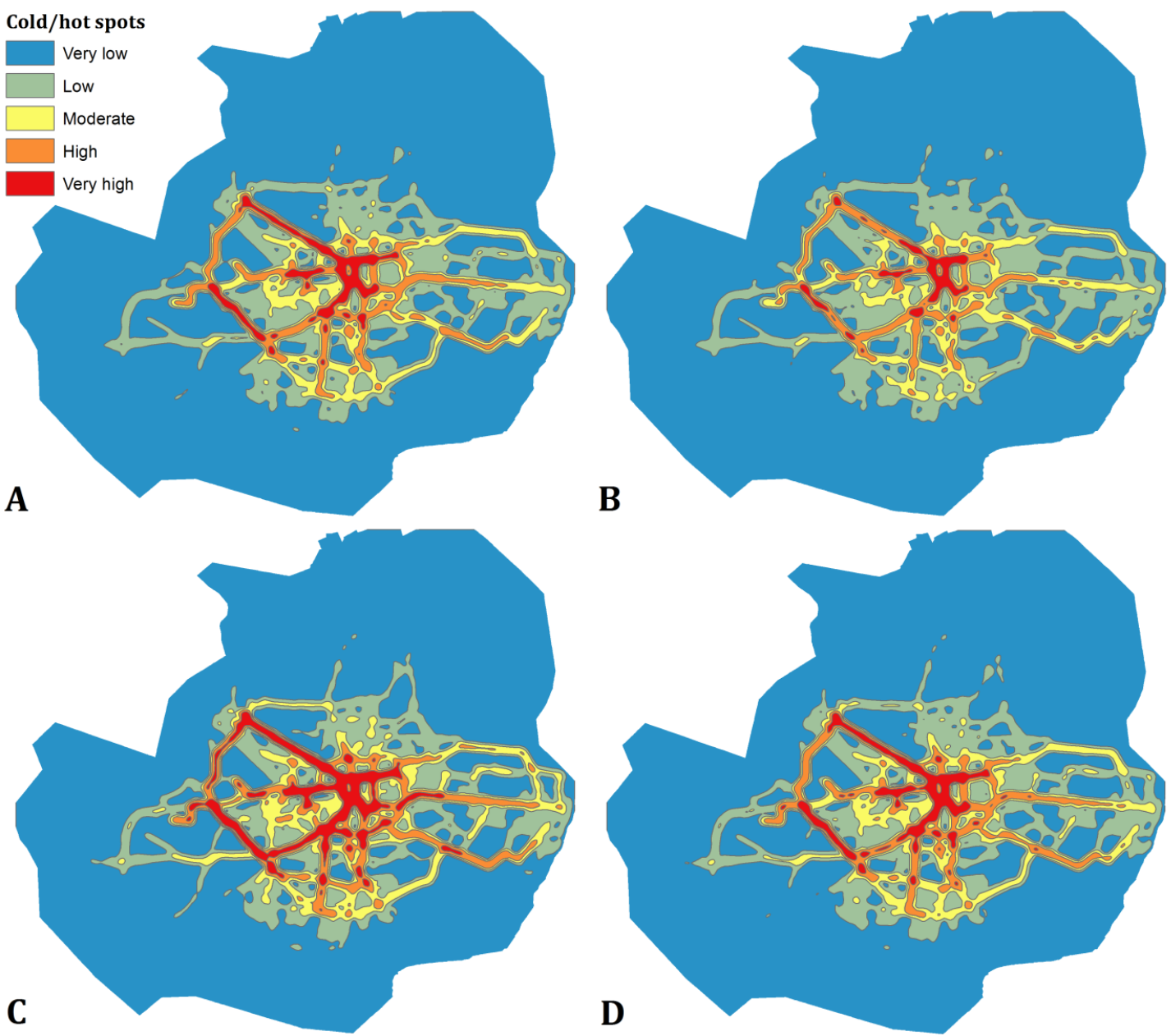

the highest increase of scooter riders in comparison to the present situation, several additional routes are identified as hotspots. The areas classified as "very high" in scenario B, which has the lowest increase in scooter riders in comparison to the present situation, gradually increase in size in the other three scenarios.

The proportional distribution of the population over the five impact classes for $\mathrm{CO}, \mathrm{NO}_{\mathrm{x}}$ and $\mathrm{HC}$ is different in each scenario (Table 7). Scenarios $B$ and $D$ have the largest growth in the number of scooter riders, and correspondingly, in those scenarios $30 \%-47 \%$ of the population will experience "high - very high" disturbance from exhaust gases from scooters. The number of affected childcare facilities per impact class varies between the four scenarios. Table 8 shows the ranges, with most of variability in the "very high" impact class.

This can be explained by Figure 7, which zooms into one area in the city. The highest $\mathrm{CO}$ impact buffer of scenario $B$ is considerably smaller than the impact buffer of scenario $C .17$ childcare locations are 'spared' by the scenario $B$ buffer but fall within the buffer in scenario $C$. These childcare locations are mostly located in the south-eastern part of the city around the city beltway. It appears that in the future many childcare facilities located in the inner city will fall within the "very high" impact class. This should be considered when deciding on future childcare locations. 
Table 7. Proportion of population within each impact class for $\mathrm{CO}, \mathrm{NO}_{\mathrm{x}}$ and $\mathrm{HC}$ for all four future scenarios.

\begin{tabular}{|c|c|c|c|c|c|c|c|}
\hline \multirow{2}{*}{ Impact class } & $\mathrm{CO}$ & $\mathrm{NO}_{\mathrm{x}}$ & $\mathrm{HC}$ & Impact clas & $\mathrm{CO}$ & $\mathrm{NO}_{x}$ & $\mathrm{HC}$ \\
\hline & $\%$ & $\%$ & $\%$ & & $\%$ & $\%$ & $\%$ \\
\hline \multicolumn{4}{|l|}{ Scenario A } & \multicolumn{4}{|l|}{ Scenario C } \\
\hline Very low & 9 & 12 & 9 & Very low & 7 & 9 & 6 \\
\hline Low & 29 & 32 & 28 & Low & 23 & 27 & 23 \\
\hline Moderate & 19 & 20 & 19 & Moderate & 20 & 21 & 19 \\
\hline High & 23 & 21 & 24 & High & 19 & 18 & 20 \\
\hline Very high & 20 & 15 & 20 & Very high & 31 & 25 & 32 \\
\hline \multicolumn{4}{|l|}{ Scenario B } & \multicolumn{4}{|l|}{ Scenario D } \\
\hline Very low & 11 & 14 & 10 & Very low & 9 & 11 & 8 \\
\hline Low & 30 & 34 & 29 & Low & 27 & 31 & 27 \\
\hline Moderate & 21 & 22 & 21 & Moderate & 18 & 19 & 18 \\
\hline High & 24 & 20 & 25 & High & 22 & 21 & 23 \\
\hline Very high & 14 & 10 & 15 & Very high & 24 & 18 & 24 \\
\hline
\end{tabular}

Table 8. Range of the absolute number of childcare facilities per impact area for $\mathrm{CO}, \mathrm{NO}_{\mathrm{x}}$ and $\mathrm{HC}$ in the four future scenarios

\begin{tabular}{lllllll} 
Impact class & $\mathrm{CO}$ & \multicolumn{2}{c}{$\mathrm{NO}_{\mathrm{x}}$} & \multicolumn{2}{l}{$\mathrm{HC}$} \\
& Lowest-highest & Range & Lowest-highest & Range & Lowest-highest & Range \\
Very low & $0-5$ & 5 & $1-8$ & 7 & $0-5$ & 5 \\
Low & $23-33$ & 10 & $33-40$ & 7 & $22-31$ & 9 \\
Moderate & $15-26$ & 11 & $13-20$ & 7 & $16-26$ & 10 \\
High & $14-24$ & 10 & $23-27$ & 4 & $13-23$ & 10 \\
Very high & $19-36$ & 17 & $11-20$ & 9 & $20-38$ & 18
\end{tabular}

The results for noise impacts are presented in Table 9. Again, the largest differences are in the highest impact class. The scenarios $A, B$ and $D$ resemble each other the most, while scenario $C$ can be seen more as an outlier. According to scenario $C, 51 \%$ of Enschede residents will experience a "high - very high" noise disturbance from scooters.

At least $19 \%$ of the childcare locations will experience a very high disturbance from scooters noise exhaust. This percentage can increase to $38 \%$ in the scenario with the highest increase in scooter numbers.

The "high - very high" impact areas for scooter accidents in all four scenarios were merged. Intersections in those merged areas within 50 meters from past scooter accidents were selected and presented in Figure 8. 
In Table 10 the proportion of population within the two highest impact classes for both present

Figure 7. Differences between affected childcare locations (red) in the CO highest impact buffers in scenario B (light blue) and in scenario C (dark blue)

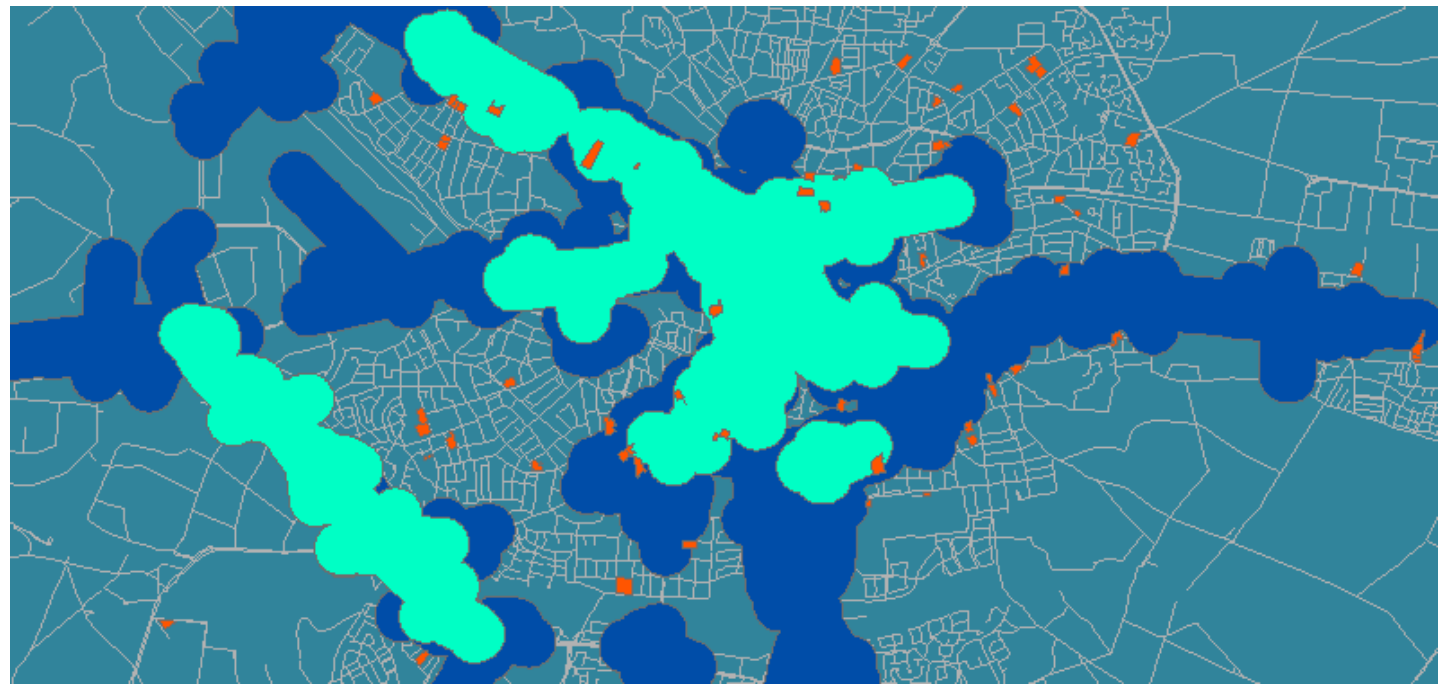

Table 9. Proportion of population within noise impact classes in all four scenarios

\begin{tabular}{llll} 
Impact class & Noise \% & Impact class & Noise \% \\
Scenario A & \multicolumn{3}{l}{ Scenario C } \\
Very low & 9 & Very low & 6 \\
Low & 28 & Low & 22 \\
Moderate & 19 & Moderate & 21 \\
High & 24 & High & 19 \\
Very high & 20 & Very high & 32 \\
Scenario B & & Scenario D &
\end{tabular}

$\begin{array}{llll}\text { Very low } & 10 & \text { Very low } & 8 \\ \text { Low } & 29 & \text { Low } & 27 \\ \text { Moderate } & 21 & \text { Moderate } & 18 \\ \text { High } & 26 & \text { High } & 23 \\ \text { Very high } & 14 & \text { Very high } & 24\end{array}$

and future situations are presented. In the worst-case scenario, $\mathrm{C}$, the increase in affected residents in the municipality will be approximately around 26,000 .

Also, in this table we see that in scenario $B$ the number of affected childcare locations remains the same as at present. The places where the noise buffer from scenario $B$ is extended in comparison to the present situation, no childcare facilities are currently located. Also note the steep increase in the number of childcare locations affected by $\mathrm{NO}_{x}$.

To conclude, we can expect that the adverse impacts from scooters will increase in the future. The exact degree of this expansion is not certain, but the four future scenarios show that at least 6,000 additional residents can be impacted by the exhaust/noise pollution. With regard to childcare, 3 to 22 more locations can be affected. 
Table 10. Proportion of population (\%\%) and childcare facilities affected by exhaust and noise within the two highest impact classes.
Population
Number of childcare facilities

$\begin{array}{lllllll}\text { Factors } & \text { Present } & \text { Future } & \begin{array}{l}\text { Number of } \\ \text { additional people } \\ \text { affected }\end{array} & \text { Present } & \text { Future } & \begin{array}{l}\text { Number } \\ \text { added }\end{array} \\ \mathrm{CO} & 34 & 38-50 & 6,905-27,324 & 38 & 42-50 & 4-12 \\ \mathrm{NO}_{\mathrm{x}} & 27 & 30-43 & 5,678-25,840 & 23 & 34-45 & 11-22 \\ \mathrm{HC} & 36 & 40-52 & 7,020-26,316 & 40 & 43-51 & 3-11 \\ \text { Noise } & 36 & 40-51 & 7,436-25,817 & 41 & 41-51 & 0-10\end{array}$

\section{Discussion}

Our analysis shows that the proportion of the population that is impacted is quite high - up to $36 \%$.

This is quite close to the results of a survey, when in 2010 a group of residents from the municipality of Enschede was asked about sources of noise they experienced daily in the last twelve months. $33 \%$ of respondents from the Panel indicated that noise disturbance caused by scooters and motorcycles was their highest concern (I\&O research, 2010).

This is probably the only clear evidence that we have for verification of our results. Actual data on exhaust gases concentrations are not available. Still we believe that the analyses performed raises enough concerns for environmental managers and policy makers to consider some changes in existing PTW regulations.

The buffers used in our analysis were homogeneous, which means that the diffusion of exhaust gases is high along the roads and gradually decreases with distance. Residents living directly along the roads are of course most impacted by scooter exhaust/noise. The impact on the population falling within the "moderate" impact class, but living directly along the roads, is probably underestimated. According to literature, especially the $\mathrm{NO}_{x}$ and $\mathrm{HC}$ result in adverse health effects. This means that within the areas where a "high - very high" impact of $\mathrm{NO}_{x}$ is expected, also the impact of $\mathrm{HC}$ is "high - very high". $\mathrm{NO}_{x}$ has the lowest distance decay parameter of $115 \mathrm{~m}$. At present the proportion of population living in those areas is $27 \%$. This proportion increases in the future to $30.5 \%-43 \%$. The number of childcare facilities affected by noise/exhaust emission is quite alarming, especially keeping in mind that children are more sensitive to both noise and exhaust emissions. With regard to the 
noise emissions, at present already $41 \%$ of the childcare facilities are located in "high - very high" impact areas. In the future this proportion can rise to $51 \%$.

Yet another group of the population, which we have not considered separately are the bicycle riders, who probably suffer the most from light mopeds, with which they have to share the road. Bearing in mind the close proximity of bike riders to the sources of exhaust and the elevated respiration levels due to their own pedaling, the health implications for them are probably most severe. Pedestrians will be most affected as well.

There was a number of assumptions that were made to conduct this analysis (a full list is given in Table 1A in the Appendix). The results are certainly sensitive to the assumptions made. The literature on the impact of different scooter types (two-stroke/four-stroke, euroclasses and (light-) mopeds) with regard to the exhaust and noise pollution is also quite limited. As more data is acquired some of these assumptions can be replaced with data. Still, the developed assessment script can be used to refine the routes taken by scooter riders to their work, education or shop location. In future studies it would be good to distinguish between the light-moped and moped networks, since their impact on health can be substantially different, bearing in mind that it is more likely for light-mopeds to have a cheaper 2-stroke engine. Using better diffusion models would result in more heterogeneous buffers around the roads, and consequently in more accurate estimates of the impacted population.

\section{Conclusions}

A scoping analysis of scooter impacts on the population in a typical Dutch municipality has been conducted, using open data and GIS tools. As can be expected, the major scooter routes are found in the city center. The highest concentrations of scooters are around the railway station and at junctions on major exit roads. The side of the inner city that had more employment opportunities (West), also has more scooter traffic. It was also not far from the next big city in this area, Hengelo, which is close enough to be reached by scooter. According to future scenarios, traffic counts in the inner city and on western exit roads will increase.

We have focused on the impact of four exhaust gases: $\mathrm{CO}, \mathrm{NO}_{x}$ and $\mathrm{HC}$, which are already regulated by law for cars, but not for scooters. Distance decay parameters for these compounds were taken from literature. $\mathrm{CO}$, which can cause reduced blood oxygen, has a "high/very high" impact on $34 \%$ of the present population. In the future scenarios, this proportion can increase to $38 \%-51 \%$.

$\mathrm{NO}_{\mathrm{x}}$, which is associated with respiratory illness, asthma, or eye irritation, and which is most harmful for children, has a "high/very high" impact on $27 \%$ of the present population. In the future the percentage also increases, but not as much (to $30 \%-43 \%$ ). At present 23 out of 99 childcare facilities are located within the impacted areas. This is alarming, bearing in mind the sensitivity of children to $\mathrm{NO}_{\mathrm{x}}$. Even more alarming is that in the future this number may increase to 45 .

$\mathrm{HC}$ has the same health impacts as $\mathrm{NO}_{\mathrm{x}}$, and is also bad for kids. The "high/very high" impact is currently seen by $36 \%$ of the population. This proportion increases to $40 \%-52 \%$ in the future. At present 40 childcare facilities are located within the high impact areas. In the future this can increase to $43-51$.

Although the distance decay parameter for noise is 240 meters and is larger than that for $\mathrm{HC}$ (180 meters), noise is well absorbed by buildings. We have decreased the distance decay parameter by the proportion of buildings within the first 100 meters from the road. The spatial impact of scooter noise was more or less the same with $36 \%$ of the population impacted at present, and rising to $40-53 \%$ in the future. The impacted number of childcare facilities currently is 41 , which can grow in the future by 11 .

Approximately $88 \%$ of scooter related accidents occur within 50 meters from intersections, with the largest numbers within the first 10 meters. The maps of scooter activity that were generated are well correlated with the data on accidents. The areas classified as "high/very high chance of encountering a scooter", were also responsible for most of the accidents $(37 \%)$. The areas were the chance of scooter accidents is higher than moderate include the inner-city roads, the city beltway, the western exits roads and the two exit roads. 
In terms of methodology this research demonstrates that using GIS methods we can produce quite extensive spatial analyses of traffic routing and estimate the associated environmental impacts. Only publicly available data were used, which bears promise that similar environmental impact assessment can be conducted in other areas in the Netherlands and, perhaps, elsewhere where scooters are becoming a problem.

Our overall conclusion is that scooter related air pollution, noise pollution and elevated probability of accidents are affecting about $30 \%$ of the local population, and that this number is likely to increase to $38 \%-53 \%$ in the future. This certainly should be a major concern for the policy makers and begs for some mitigation actions. These could range from regulations, such as restricting scooters from city center and bike lanes, to market mechanisms, such as subsidies that could help convert the scooter fleet to electric power. Perhaps some lessons could be learned from scooter control in China, where only electric scooters (e-scooters) are allowed in major cities. Electric scooters are certainly to prevail in the future and the recent news about the electric option offered by Vespa, the iconic Italian scooter manufacturer, gives more hope for a fast transition ${ }^{1}$.

With regard to the exhaust impact and noise, the e-scooters can completely solve this problem. They produce approximately 20 decibels lower noise levels (Fiebig, 2012). In fact this is sometimes even seen as a problem: cyclists and pedestrians can be unaware of approaching scooters because they are so quiet - an issue that is also raised for electric cars (SWOV, 2011). Since the speed difference between light-mopeds and cyclists on the cycling paths is large, a solution could be to put the light-mopeds also on the car lanes, as it is the case with mopeds.

Aiming at the reduction of scooter accidents, several improvements can be enforced by law. Light-mopeds could also be removed from the cycling paths. Research in Amsterdam predicts that putting light-mopeds on car lanes instead of cycling paths can reduce the number of scooter related accidents by 250 . The safety can be further improved by making helmets mandatory for light-mopeds as already required for mopeds (SWOV, 2014). This is a solution, which would at least diminish the severity of scooter accidents, however it will not help cyclists and pedestrians if involved. It may also decrease the 'excitement' and ' sensationseeking' factors that tend to make scooters especially popular among youngsters. Removal of scooters from bike lanes would be certainly much appreciated by the cyclists, whose exposure to poisonous emissions and noise is disproportionally high. The city Center, which has the highest concentration of pedestrians, will certainly also benefit the most from restrictions on scooter traffic.

\section{References}

Albert, D. P., Gesler, W. M., \& Levergood, B. (2000). Spatial analysis, GIS, and remote sensing applications in the health sciences. Chelsea, Mich.: Ann Arbor Press.

Antunes, P., Santos, R., \& Jordão, L. (2001). The application of Geographical Information Systems to determine environmental impact significance. Environmental Impact Assessment Review, 21(6), 511-535.

ArcGIS. (2014). How kernel density works Retrieved 23 September 2014, from http://help.arcgis.com/en/arcgisdesktop/10.0/help/index.html\#/How Kernel Density works/00 $\underline{\text { 9z00000011000000/ }}$

Biju, B., \& Vijayan, N. (2014). Estimation of health impact due to air pollution in Thiruvananthapuram City. International Journal of Innovative Research in Science, Engineering and Technology, 3(7), 8.

\footnotetext{
1 https://reneweconomy.com.au/vespa-says-its-electric-scooters-are-finally-going-intoproduction-16126/
} 
Blackman, R. A., \& Haworth, N. L. (2013). Comparison of moped, scooter and motorcycle crash risk and crash severity. [Article]. Accident Analysis and Prevention, 57, 1-9. doi: 10.1016/j.aap.2013.03.026

Brook, R. D., \& Rajagopalan, S. (2009). Particulate matter, air pollution, and blood pressure. Journal of the American Society of Hypertension, 3(5), 332-350. doi: http://dx.doi.org/10.1016/j.jash.2009.08.005

Boogaard, Hanna \& Borgman, Frank \& Kamminga, Jaap \& Hoek, Gerard. (2009). Exposure to ultrafine and fine particles and noise during cycling and driving in 11 Dutch cities. Atmospheric Environment. 43. 4234-4242. 10.1016/j.atmosenv.2009.05.035.

Cai, X. J., Wu, Z. F., \& Cheng, J. (2013). Using kernel density estimation to assess the spatial pattern of road density and its impact on landscape fragmentation. [Article]. International Journal of Geographical Information Science, 27(2), 222-230. doi: 10.1080/13658816.2012.663918

CBS. (2013). Bromfietsen; aantal per 1000 inwoners, soort voertuig en regio op 1 januari [online] Retrieved 27 October 2013, from http://statline.cbs.nl/StatWeb/publication/?DM=SLNL\&PA=81568NED\&D1=0\&D2=12\&D3=0\&D4=a\&HDR=T,G1\&STB=G2,G3\&VW=T

CBS. (2014a). Bromfietsen; aantal (per 1000 inwoners), soort voertuig, regio's, 1 januari Retrieved 14 September 2014, from http://statline.cbs.nl/Statweb/publication/?DM=SLNL\&PA=81568NED\&D1=0\&D2=12\&D3=131\&D4=a\&VW=T

CBS. (2014b). Onderzoek Verplaatsingen in Nederland (OViN) Retrieved 15 February 2014, from http://www.cbs.nl/nl-NL/menu/informatie/deelnemers-enquetes/personenhuishoudens/ovin/doel/default.htm

Cohen, L. (2012). Berlage of Barlaeus? Het schoolkeuzeproces door de ogen van Amsterdamse ouders [online] Retrieved 14 April 2014, from http://www.amsterdam.nl/publish/pages/468529/rapport schoolkeuze def.pdf

Dall'Osto, M., \& Querol, X. (2013). New Directions: Four to two - Powered two wheelers changing the European urban motor vehicle census. Atmospheric Environment, 77(0), 10831084. doi: http://dx.doi.org/10.1016/j.atmosenv.2013.05.061

Dienst Uitvoering Onderwijs. (2014). Deelnemers per instelling, plaats, type mbo, woongemeente, provincie, deelnemer, leeftijd [online]. Retrieved from http://www.duo.nl/organisatie/open onderwijsdata/databestanden/mbo/Onderwijsdeelnemer s/Onderwijsdeelnemers/mbo deelname11.asp [cited 24 April 2014]

Dijkers, J., \& Visser, G. J. (2012). Mobiliteitsstromenonderzoek Twente [online] Retrieved 23 February 2014, from

http://www.regiotwente.nl/images/website/voor de burger/wegen/Mobiliteitsstromen/Mobiliteit sstromenonderzoek Twente.pdf

Dijkgraaf, E., Gradus, R. H. J. M., \& de Jong, J. M. (2013). Competition and educational quality: Evidence from the Netherlands. Empirica, 40(4), 607-634.

Dröge, R., Hensema, A., ten Broeke, H., \& Hulskotte, J. (2011). Emissions of two-wheeled vehicles. Utrecht: TNO.

Ewalds, D., Mortiz, G., \& Sijstermans, M. (2013). Bromfietsen in Nederland 2013. Den Haag/Heerlen: Centraal Bureau voor de Statistiek.

Favarato, G., Anderson, H. R., Atkinson, R., Fuller, G., Mills, I., \& Walton, H. (2014). Trafficrelated pollution and asthma prevalence in children. Quantification of associations with nitrogen dioxide. Air Quality, Atmosphere \& Health.

Fiebig, A. (2012). Reducing noise levels and annoyance of powered-two wheelers in cities. Paper presented at the CityHush workshop - Acoustically green cities, Perugia.

Gemeente Enschede. (2011). Detailhandelstructuurvisie Enschede 2011 [online] Retrieved 19 February 2014, from http://ris.enschede.nl/stukken/08996/download.html 
Gemeente Enschede. (2014). Statistisch jaarboek 2014 [online] Retrieved 13 September 2014, from

http://kennispunttwente.nl/images/cijfers/Enschede/Statistisch jaarboek 2014/Seic201402.pdf

Genuit, K. (2013). What will be the influence of e-mobility on soundscape? Proceedings of Meetings on Acoustics, 19(1), -. doi: doi:http://dx.doi.org/10.1121/1.4800426

Habermann, M., Medeiros, A. P. P., \& Gouveia, N. (2011). Vehicular traffic as a method to evaluate air pollution in large cities. Revista Brasileira de Epidemiologia, 14, 120-130.

Haworth, N. (2012). Powered two wheelers in a changing world - Challenges and opportunities. Accident Analysis and Prevention, 44(1), 12-18. doi: 10.1016/j.aap.2010.10.031

Heil, M., \& Pargal, S. (1998). Reducing air pollution from urban passenger transport : a framework for policy analysis / by Mark Heil and Sheoli Pargal. Washington, DC: World Bank, Development Research Group, Infrastructure and Environment.

Hensema, A., \& Roeterdink, W. (2009). De effecten van brommers op de luchtkwaliteit in de gemeente Amsterdam. Delft: TNO.

Hensema, A., van Mensch, P., \& Vermeulen, R. (2013). Tail-pipe emissions and fuel consumption of standard and tampere mopeds. Delft: TNO.

I\&O research. (2010). Het Enschedepanel over bedrijvigheid, bodemverontreiniging en geluidsoverlast [online] Retrieved 3 October 2014, from http://portal.gmimr.com/207685/9/EnschedePortal/resultaten/aep10benm rapportage.pdf

Jerrett, M., Arain, A., Kanaroglou, P., Beckerman, B., Potoglou, D., Sahsuvaroglu, T., . . . Giovis, C. (2005). A review and evaluation of intraurban air pollution exposure models. Journal of Exposure Analysis and Environmental Epidemiology, 15(2), 185-204.

Kalshetty, B., \& Karalatti, B. (2013). Study on noise pollution of industrialized and urbanized towns like Rabakavi and Banahatti of Bagalkot district, Karnataka state, India. International Journal of Science \& Nature, 4(4), 5.

Karner, A. A., Eisinger, D. S., \& Niemeier, D. A. (2010). Near-Roadway Air Quality: Synthesizing the Findings from Real-World Data. Environmental Science \& Technology, 44(14), 5334-5344. doi: 10.1021/es100008x

Kences. (2013). Landelijke monitor studenthuisvesting. Enschede 2013 [online] Retrieved 24 April 2014, from http://www.wonenalsstudent.nl/assets/files/Lokale\%20rapportages\%202013/Apollo2013 bep erkt Enschede.pdf

Kirrane, E., Loomis, D., Egeghy, P., Nylander-French (2007). Personal exposure to benzene from fuel emissions among commercial fishers: Comparison of two-stroke, four-stroke and diesel engines. Journal of exposure science \& environmental epidemiology. 17. 151-8. 10.1038/sj.jes. 7500487 .

Li, X. L., Han, J. W., Lee, J. G., \& Gonzalez, H. (2007). Traffic density-based discovery of hot routes in road networks. In D. Papadias, D. Zhang \& G. Kollios (Eds.), Advances in Spatial and Temporal Databases, Proceedings (Vol. 4605, pp. 441-459). Berlin: Springer-Verlag Berlin.

Methorst, R., Schepers, J., \& Vermeulen, W. (2011). Snorfiets op het fietspad. Delft: Rijkswaterstaat.

Mohapatra, K. M. (2004). Technology, environment and human values : a metaphysical approach to sustainable development. New Delhi: Concept Pub.

Njå, O., \& Nesvåg, S. M. (2007). Traffic behaviour among adolescents using mopeds and light motorcycles. Journal of Safety Research, 38(4), 481-492.

Ntziachristos, L., Mamakos, A., Samaras, Z., Xanthopoulos, A., \& lakovou, E. (2006). Emission control options for power two wheelers in Europe. Atmospheric Environment, 40(24), 4547-4561. doi: 10.1016/j.atmosenv.2006.04.003 
Passchier-Vermeer, Willy \& Passchier, Wim. (2000). Noise Exposure and Public Health. Environmental health perspectives. 108 Suppl 1. 123-31. 10.2307/3454637.

Paviotti, M., \& Vogiatzis, K. (2012). On the outdoor annoyance from scooter and motorbike noise in the urban environment. Science of the Total Environment, 430, 223-230. doi: 10.1016/j.scitotenv.2012.05.010

Prati, M. V., \& Costagliola, M. A. (2009). Emissions of fine particles and organic compounds from mopeds. Environmental Engineering Science, 26(1), 111-121. doi: 10.1089/ees.2007.0206

Rana, S. V. S. (2008). Energy, ecology and environment. New Delhi: I.K. International Publishing House.

Rijksdienst voor Ondernemend Nederland. (2014). Transformatie en geluid van het expertteam (kantoor) transformatie Retrieved 12 September 2014, from http://www.rvo.nl/sites/default/files/2014/04/Transformatie\%20en\%20geluid.pdf

Rijksoverheid. (2013). Mag ik met mijn brommer of snorfiets op het fietspad rijden? [online]. Retrieved from http://www.rijksoverheid.nl/onderwerpen/bromfiets/vraag-en-antwoord/mag-ikmet-mijn-bromfiets-brommer-scooter-of-snorfiets-op-het-fietspad-rijden.html [cited 23-102013]

Rijkswaterstaat. (2010). Geluid luistert nauw. Informatie over bestrijding van wegverkeerslawaai [online] Retrieved 18 May 2014, from http://www.rijkswaterstaat.nl/images/Brochure\%20Geluid\%20Luistert\%20Nauw tcm174310219.pdf

Rijkswaterstaat. (2011). Hoe wordt de luchtkwaliteit langs autosnelwegen bepaald? [online] Retrieved 13 May 2014, from

http://www.rijkswaterstaat.nl/images/Brochure\%20luchtkwaliteit\%20december\%202011 tcm1 74-318172.pdf

Santamouris, M. (2006). Environmental design of urban buildings an integrated approach, from http://public.eblib.com/choice/publicfullrecord.aspx? $p=430172$

SCI. (2014). Indicator TR.3.b Traffic density [online] Retrieved 28 August 2014, from http://www.sustainablecommunitiesindex.org/indicators/view/46

Severijn, J., \& Esselink, R. (2012). Monitor Economische Ontwikkeling Enschede Retrieved 12 February 2014, from http://ondernemen.enschede.nl/bestanden/MonitorEconomische Ontwikkeling Enschede 2012 rapport juni 2013.pdf/

Steg, L., \& Brussel, A. v. (2009). Accidents, aberrant behaviours, and speeding of young moped riders. Transportation Research Part F: Traffic Psychology and Behaviour, 12(6), 503511. doi: http://dx.doi.org/10.1016/j.trf.2009.09.001

SWOV. (2009). SWOV-Factsheet. Brom- en snorfiets. Leidschendam: SWOV.

SWOV. (2011). Dutch national bicycle safety research agenda: the way to safer cycling [online] Retrieved 24 September 2014, from http://www.swov.nl/rapport/Ss RA/RA47.pdf

SWOV. (2014). SWOV factsheet. Brom- en snorfietsers Retrieved 24 September 2014, from http://www.swov.nl/rapport/Factsheets/NL/Factsheet Bromsnorfietsers.pdf

Valero, X., \& Alias, F. (2013). Hierarchical Classification of Environmental Noise Sources Considering the Acoustic Signature of Vehicle Pass-Bys (Vol. 37).

Vos, J. (2006). Noise annoyance caused by mopeds and other traffic sources. Proceedings Internoise 2006, Honolulu, Hawaï.

VROM. (2010). Beperking geluidsoverlast uitlaatsystemen brommers en motoren. Een onderzoek naar interventiemogelijkheden. Retrieved 14 December 2013, from http://www.ilent.nl//mages/0180\%20Beperking\%20geluidoverlast\%20uitlaatsystemen\%20bro mmers\%20en\%20motoren tcm334-320301.pdf

Weijer van de, B. (2014). Tweetaktscooter nog grotere vervuiler dan gedacht [online].

Volkskrant Retrieved 16 May 2014, from 
http://www.volkskrant.nl/wetenschap/tweetaktscooter-nog-grotere-vervuiler-dangedacht a3654566/

Please replace (Kadaster, 2014) with https://business.gov.nl/regulation/addresses-andbuildings-key-geo-register/

Kirrane, E., Loomis, D., Egeghy, P., Nylander-French (2007). Personal exposure to benzene from fuel emissions among commercial fishers: Comparison of two-stroke, four-stroke and diesel engines. Journal of exposure science \& environmental epidemiology. 17. 151-8. 10.1038/sj.jes.7500487.

Boogaard, Hanna \& Borgman, Frank \& Kamminga, Jaap \& Hoek, Gerard. (2009). Exposure to ultrafine and fine particles and noise during cycling and driving in 11 Dutch cities. Atmospheric Environment. 43. 4234-4242. 10.1016/j.atmosenv.2009.05.035.

Passchier-Vermeer, Willy \& Passchier, Wim. (2000). Noise Exposure and Public Health. Environmental health perspectives. 108 Suppl 1. 123-31. 10.2307/3454637.

den Boer, L.C., Schroten, A., 2007. Traffic noise reduction in Europe. 4.451.1/CE Delft, March 2007

Please replace EPA, 1991 with: Gabele, P.A., 2000. Characterization of Emissions from Hand-held Two-stroke Engines. EPA/600/A-

00/012. https://nepis.epa.gov/Exe/ZyPURL.cgi?Dockey=P100GDP7.TXT

Please replace Dost 2010 with: Dost, F.N., 2003. Toxicology and potential health risk of chemicals that may be encountered by workers using forest vegetation management options. Part I, Risk to workers associated with exposure to emissions from power saws. 24 p.

https://www.for.gov.bc.ca/hfp/publications/00012/3-dost-powersawemissions.pdf

\section{Uncited references}

Antunes et al., 2001; ArcGIS, 2014; Cohen, 2012; Dienst Uitvoering Onderwijs, 2014; Dijkers and Visser, 2012; Dijkgraaf et al., 2013; Dröge et al., 2011; Enschede, 2014; Genuit, 2013; Hensema and Roeterdink, 2009; Kalshetty and Karalatti, 2013; Karner et al., 2010; Kences, 2013; Ntziachristos et al., 2006; Rijksdienst voor Ondernemend Nederland, 2014; Rijkswaterstaat, 2011; Santamouris, 2006; Severijn and Esselink, 2012; Valero and Alias, 2013. 